\title{
INITIATIVES FOR THE IMPLEMENTATION OF REGIONAL CROWDFUNDING SYSTEMS IN THE FINANCIAL GROUP OF GERMAN SAVINGS AND VOLKS- RAIFFEISEN BANKS \\ Dariusz T. Dziuba
}

Full Professor, Faculty of Economics, University of Warsaw, Długa St. 44/50, 00-241 Warszawa, Poland.

Email: dziubadt@wne.uw.edu.pl

Article History: Received on $14^{\text {th }}$ June 2021, Revised on $27^{\text {th }}$ June 2021, Published on $11^{\text {th }}$ July 2021

\section{Abstract}

Purpose of the Study: The subject of consideration is crowdfunding as an innovative method of acquiring sponsors for the implementation of projects. The considerations were devoted to the initiatives of the Sparkassen-Finanzgruppe and the Volks-Raiffeisen banks in the implementation of regional crowdfunding systems in these banks. The aim of the research was to answer the following question: what are the sizes (in terms of value and quantity) of the analyzed market sub-segment and its specificity.

Methodology: Crowdfunding platforms were identified at individual savings banks and VR banks. The data was searched on internet resources, supported by, inter alia, lists of such financial institutions. The final data was obtained directly from the websites of financial institutions, or they were aggregated. The research was carried out at the turn of May and June 2021, with data verification as of June 7, 2021.

Main Findings: The article explores a specific market segment in Germany - savings banks and Volks-Raiffeisen banks that implement donation crowdfunding platforms. The scope of implementation of such systems was determined by identifying individual analyzed financial institutions. Methods of project co-financing by banks were highlighted. The value of accumulated financial resources (capital) and the scope of project implementation were measured, separating the size of the market sub-segment under study. The examined systems collectively obtained a relatively large amount, over EUR 86.3 million.

Applications of the Study: The presented article relates to the use of crowdfunding methods in selected financial institutions: German savings banks and VR banks. This implies considerations in several scientific fields, incl. economics and finance (the possibility of measuring the market segment; the specificity of banks' operation), IT (in economic applications), or sociology (relations between donors / sponsors and financial institutions).

Novelty / Originality of this Study: Scientific literature on the use of crowdfunding in financial institutions, in particular the measurement of the size of this market segment, is practically non-existent. Thus, getting to know the specifics and distinguishing in this article the size (in terms of value and quantity) of the crowdfunding sub-segment in German savings banks and VR banks, although partial, seems promising. This opens a pool of further studies in this area with the possibility of comparing them.

Keywords: Crowdfunding, Regional Platforms, Donation-based Model, Volks- Raiffeisen Banks, Sparkassen. 


\title{
INICJATYWY WDRAŻANIA REGIONALNYCH SYSTEMÓW CROWDFUNDINGU W GRUPIE FINANSOWEJ NIEMIECKICH KAS OSZCZĘDNOŚCIOWYCH I BANKACH VOLKS- RAIFFEISEN
}

\author{
Dariusz T. Dziuba
}

Prof. dr hab., Wydział Nauk Ekonomicznych, Uniwersytet Warszawski, Długa 44/50, 00-241 Warszawa, Polska. Email: dziubadt@wne.uw.edu.pl

\author{
Historia artykułu: Otrzymano 14 czerwca 2021, Poprawiono 27 czerwca 2021, Opublikowano 10 lipca 2021
}

\begin{abstract}
Abstrakt
Cel badawczy: Przedmiotem rozważań jest crowdfunding, jako innowacyjna metoda pozyskiwania sponsorów dla realizacji projektów. Rozważania poświęcono inicjatywom grupy finansowej kas oszczędnościowych oraz banków Volks- Raiffeisen (VR), w zakresie wdrażania w tych instytucjach regionalnych systemów crowdfundingu. Celem badań było uzyskanie odpowiedzi następujące pytanie: jakie są rozmiary (w kategoriach wartościowych i ilościowych) analizowanego sub-segmentu rynkowego oraz jego specyfika.
\end{abstract}

Metoda badawcza: Dokonano identyfikacji platform crowdfundingu w poszczególnych kasach oszczędnościowych i bankach VR. Dane wyszukiwano w zasobach internetowych, wspomagając się m.in. listami takich instytucji finansowych. Finalne dane czerpano bezpośrednio ze stron Web instytucji finansowych, bądź dokonywano ich agregacji. Badań dokonano na przełomie maja i czerwca 2021r., z weryfikacją danych według stanu na 7.06.2021r.

Uzyskane wyniki: W artykule udało się zbadać specyficzny segment rynkowy w Niemczech - kasy oszczędnościowe i banki Volks- Raiffeisen, wdrażające donacyjne platformy crowdfundingu. Określono zakres implementacji takich systemów identyfikując poszczególne analizowane instytucje finansowe. Uwypuklono metody współfinansowania projektów przez banki. Dokonano pomiaru wartości gromadzonych środków finansowych (kapitału) i zakresu realizacji projektów, wydzielając rozmiary badanego sub-segmentu rynkowego. Badane systemy łącznie pozyskały relatywnie dużą kwotę, ponad 86.3 miliona euro.

Zastosowania badań: Prezentowany artykuł odnosi się do zastosowań metod crowdfundingu w wybranych instytucjach finansowych: niemieckich kasach oszczędnościowych i bankach VR. Implikuje to przemyślenia w kilku dziedzinach naukowych, m.in. ekonomii i finansach (możliwości pomiaru segmentu rynkowego, specyfika funkcjonowania banków), informatyki (w aplikacjach ekonomicznych), czy socjologii (relacje między donatorami/sponsorami a instytucjami finansowymi).

Oryginalność badań: Literatura naukowa na temat zastosowań crowdfundingu w instytucjach finansowych, W szczególności pomiaru rozmiarów tego segmentu rynkowego praktycznie nie istnieje. A zatem poznanie specyfiki i wydzielenie w niniejszym artykule rozmiarów (w kategoriach wartościowych i ilościowych) sub-segmentu crowdfundingu w niemieckich kasach oszczędnościowych i bankach VR, choć cząstkowe, wydaje się perspektywiczne. Otwiera to pulę dalszych badań w tym zakresie z możliwością ich porównywania.

Słowa kluczowe: Crowdfunding, Regionalne Platformy, Model Donacyjny, Kasy Oszczędnościowe, Banki VolksRaiffeisen.

\section{WSTĘP}

Przedmiotem niniejszych rozważań jest crowdfunding, jako innowacyjna metoda pozyskiwania sponsorów/darczyńców dla realizacji projektów. Rozważania poświęcono inicjatywom niemieckich kas oszczędnościowych (grupy finansowej Sparkassen-Finanzgruppe) oraz banków Volks- Raiffeisen (w skrócie: VR), w zakresie wdrażania w tych instytucjach regionalnych systemów crowdfundingu.

Celem badań jest uzyskanie odpowiedzi na następujące pytanie: jakie są rozmiary (w kategoriach wartościowych i ilościowych) analizowanego sub-segmentu rynkowego oraz jego specyfika. W szczególności poszukiwano odpowiedzi na uzupełniające pytania:

- jaki jest zakres wdrożeń systemów crowdfundingu w analizowanych instytucjach; jakich platform dokonano implementacji i gdzie;

- ile w ten sposób zgromadzono środków finansowych na sfinalizowane projekty;

- w miarę dostępu do danych - jaka była struktura gromadzonego kapitału;

- czy i jakie metody (strategie) współfinansowania projektów realizują analizowane kasy i banki.

Skoncentrowano się na platformach crowdfundingu funkcjonujących według modeli donacyjnych: donacyjnych bez nagradzania i donacyjnych z nagradzaniem (tzw. sponsorskich). W kolejnych rozważaniach zaprezentowano: przegląd literatury - koncepcję i podstawowe modele crowdfundingu, z uwypukleniem zastosowań w instytucjach finansowych; proponowaną metodę badawczą; inicjatywy kas oszczędnościowych - dyskusję i wyniki badań; crowdfunding 
w bankach VR - dyskusję (w tym metody wspólfinansowania projektów) i z kolei wyniki badań; ograniczenia proponowanej metody badawczej, a reasumpcji rozważań i nakreślenie kierunków badań dokonano w podsumowaniu.

\section{CroWdFunding - KONCEPCJA I MODELE. PRZEgląd Literatury}

Literatura naukowa z zakresu crowdfundingu jest już bardzo bogata. Wymieniam tu m.in. takich autorów publikacji jak A. Agrawal, Ch. Catalini, A. Goldfarb, E.R. Mollick, R. Belleflamme, T. Lambert, A. Schwienbacher, K. Menon,

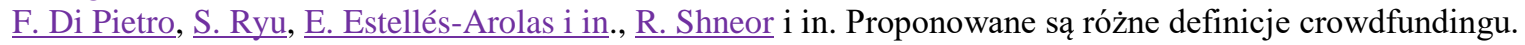

Przykładowo, T. Lambert i A. Schwienbacher (2010) podają, iż jest to wykorzystanie „mocy” thumu do finansowania przedsięwzięć, dla których pozyskiwanie kapitału tradycyjnymi metodami nie jest możliwe. Żdaniem R. Wash`a (2013: 1-2), crowdfunding to „działalność polegajaca na staraniu się poprzez otwarte zgłoszenie o pozyskanie zasobów od dużej grupy uczestników rynku, dla potrzeb realizacji nowych idei”. Th.F. Dapp (2013: 1) wskazuje, że to „(...) alternatywny typ finansowania. Oprócz ,tradycyjnych” źródet finansowania, jak venture capital, granty czy pożyczki, platformy crowdfundingu oferuja alternatywny lub komplementarny typ finansowania mniejszymi kwotami start-upów, freelancerów i kreatywnych osób (np. artystów, autorów, muzyków, dziennikarzy, projektantów itp.), bądź prywatnych pożyczkobiorców”. G. Borello (2015: 2) wskazuje, iż „crowdfunding jest nowa praktyka finansowa, poprzez która ludzie, zwykle mieszkający w różnych strefach geograficznych, uczestnicza w finansowaniu projektów dla nich interesujących; pieniadze sa gromadzone poprzez elektroniczne systemy, wykorzystujące technologię Web 2.0".

Crowdfunding internetowy (bo o nim tu mowa) jest metodą finansowania różnorodnych projektów (charytatywnych, kreatywnych, inwestycyjnych itp.) poprzez grupę internetowej społeczności. Uzyskiwane środki gromadzone są od „tłumu” internautów, zwykle jednostkowo przekazujących relatywnie niewielkie kwoty. Innymi słowy, duża liczba osób wspólnie finansuje przedsięwzięcia, umożliwiając ich realizację.

W literaturze przedmiotu i praktyce gospodarowania wydziela się zwykle kilka modeli crowdfundingu. Są one m.in. następujące: ${ }^{i}$ donacyjny bez nagradzania (non-rewards-based model), zwany charytatywnym; donacyjny z nagradzaniem (rewards-based model), zwany sponsorskim; pożyczek społecznościowych (lending-based model); inwestycyjny (investment-based model). Najbardziej rozpowszechnionym jest model donacyjny. Jego istotą jest gromadzenie poprzez platformę darowizn na zakładany cel. W „tradycyjnym” ujęciu donatorzy nie są nagradzani. Z kolei odrębny wariant - model sponsorski - gratyfikuje donatorów nagrodami niefinansowymi. Popularny jest model pożyczek społecznościowych, który pozwala na bezpośrednie pożyczanie środków finansowych, z pominięciem tradycyjnych instytucji finansowych (banków). Typowym jest również model inwestycyjny, w którym inwestorzy z internetowego „tłumu” lokują swoje wolne środki finansowe w projektach, w oczekiwaniu na korzyści finansowe; darczyńcy w zamian za okazaną pomoc finansową uczestniczą np. w zyskach przedsięwzięć, mogą otrzymywać udziały w podziale dochodów, także papiery wartościowe.

Literatura powszechnie uznaje, że crowdfunding to alternatywna metoda gromadzenia środków finansowych (kapitału) wobec banków, czy innych instytucji finansowych. Ale z drugiej strony, od ok. 10 lat można zaobserwować interesującą tendencję (Dziuba, 2021): wdrożenia platform crowdfundingu następują w skali globalnej również w bankach, co można potraktować jako paradoks. „Nasilenie” implementacji takich systemów zauważalne jest m.in. w Niemczech, co m.in. stanowi impuls do dalszych badań w tym zakresie. Ten segment rynkowy jest jeszcze w praktyce niezbadany, brakuje w szczególności pomiaru rozmiarów tego segmentu rynkowego. Niemalże nie występują publikacje z zakresu aplikacji crowdfundingu w bankach.

\section{METODA BADAWCZA}

W kolejnych rozważaniach analizowane są inicjatywy grupy finansowej Sparkassen-Finanzgruppe oraz banków Volks -Raiffeisen - (VR) w zakresie wdrażania w tych instytucjach systemów crowdfundingu. Dokonano identyfikacji takich platform w poszczególnych kasach oszczędnościowych. Dane wyszukiwano w zasobach internetowych, wspomagając się m.in. zestawieniami Sparkassen-Finanzgruppe i Sparkasse (2021), Wir ūber uns: Stark im Verbund (https://www.sparkasse.de/), także wyszukiwarki kas snet.de (Sparkassen in Deutschaland). Z kolei szczegółowo analizowano strony Web poszczególnych kas. Uzyskiwano tak informacje o dostępie do określonych platform crowdfundingu oraz statystyki dotyczące zgromadzonych środków finansowych na realizowane projekty. Finalne dane czerpano bezpośrednio ze stron internetowych instytucji finansowych, bądź dokonywano ich agregacji. Analogiczne badania przeprowadzono dla banków Volksbank-Raiffeisenbank (VR), posiłkując się w szczególności listami poszczególnych instytucji: Filialen A-Z Volksbank-Raiffeisenbank (https://www.vr.de), czy Alle Genossenschaftsbanken per Ende 2020 (https://www.bwr.de). Badań dokonano na przełomie maja i czerwca 2021r., z weryfikacją danych według stanu na 7 czerwca 2021 r.

Skoncentrowano się na platformach crowdfundingu funkcjonujących według modeli donacyjnych: donacyjnych bez nagradzania i donacyjnych z nagradzaniem (tzw. sponsorskich). Analizowane są systemy oprogramowania typu whitelabel, powielarne w licznych instytucjach finansowych, tj. platformy crowdfundingu jako usługi Software-as-a-Service (SaaS). Dostawca tych usług zapewnia klientowi (tj. danej instytucji finansowej) dostęp do gotowych aplikacji lub oprogramowania przez Internet za pomocą przeglądarki internetowej, aplikacji, albo za pomocą odpowiednio 
przygotowanego interfejsu programistycznego. W rozważaniach pominięto zatem jednostkowe ${ }^{\mathrm{ii}}$ wdrożenia systemów crowdfundingu donacyjnego w kasach oszczędnościowych.

\section{INICJATYWY KAS OSZCZĘDNOŚCIOWYCH - DYSKUSJA I WYNIKI BADAŃ}

W pierwszej części badań skoncentrowano się na kasach oszczędnościowych w Niemczech. Przeprowadzone analizy pozwoliły zidentyfikować kilka platform crowdfundingu.

Tabela 1: Platforma regionalna 99funken.de jako studium przypadku (stan na 7.06.2021r)

\begin{tabular}{|c|c|c|c|}
\hline Lp. & Wyszczególnienie & Zgromadzone środki finansowe (EUR) & Liczba projektów \\
\hline 1. & Ostsächsische Sparkasse Dresden & 1464999 & 280 \\
\hline 2. & Sparkasse Elbe - Elster & 505563 & 37 \\
\hline 3. & Ostsee Sparkasse Rostock & 365731 & 43 \\
\hline 4. & Sparkasse Vorpommern & 348758 & 83 \\
\hline 5. & Sparkasse Celle - Gifhorn - Wolfsburg & 198754 & 30 \\
\hline 6. & Sparkasse Zwickau & 194442 & 26 \\
\hline 7. & Sparkasse Chemnitz & 193537 & 33 \\
\hline 8. & Kreissparkasse Bautzen & 172480 & 23 \\
\hline 9. & Erzgebirgssparkasse & 167961 & 31 \\
\hline 10. & Sparkasse Magdeburg & 136066 & 20 \\
\hline 11. & Sparkasse Oberpfalz Nord & 120585 & 39 \\
\hline 12. & Sparkasse Oberlausitz - Niederschlesien & 106247 & 23 \\
\hline 13. & Muritz - Sparkasse & 104882 & 10 \\
\hline 14. & Sparkasse Vogtland & 91488 & 17 \\
\hline 15. & Sparkasse Neubrandenburg - Demmin & 89430 & 4 \\
\hline 16. & Sparkasse Mecklenburg - Schwerin & 72884 & 12 \\
\hline 17. & Sparkasse Mittelsachsen & 63648 & 17 \\
\hline 18. & Harzsparkasse & 55439 & 11 \\
\hline 19. & Ostdeutscher Sparkassenverband & 37090 & 2 \\
\hline 20. & Saalesparkasse & 36766 & 12 \\
\hline 21. & Sparkasse Uckermark & 36151 & 4 \\
\hline 22. & Sparkasse Mecklenburg - Nordwest & 33572 & 14 \\
\hline 23. & Sparkasse Barnim & 16810 & 4 \\
\hline 24. & Sparkasse Burgenlandkreis & 16379 & 1 \\
\hline 25. & Salzlandsparkasse & 13300 & 2 \\
\hline 26. & Sparkasse Dobeln & 10090 & 2 \\
\hline \multirow[t]{2}{*}{27.} & Sparkasse Leipzig & 2129 & 1 \\
\hline & Łącznie & 4655188 & 784 \\
\hline
\end{tabular}

Źródło: zestawienie własne bazujące na statystykach poszczególnych kas oszczędnościowych

Od roku 2019 wdrażana jest platforma 99funken.de, funkcjonująca według modelu donacyjnego z nagradzaniem (niefinansowym). To inicjatywa grupy regionalnych kas oszczędnościowych, we współpracy z Gesellschaft für Sparkassen-dienstleistungen mbH (GSD). System bazuje na zasadzie All-or-Nothing, tzn. projekt uznaje się za sfinalizowany, jeśli w wyznaczonym czasie (do maksymalnie 90 dni) zgromadzono pierwotnie zakładaną kwotę. Jak wskazują organizatorzy tego przedsięwzięcia, każde przekazane przez sponsora euro zostało podwojone (do określonej puli) przez tę kasę oszczędnościową.

W badaniach zidentyfikowano 27 kas oszczędnościowych i związek kas, wykorzystujących platformę - w tabeli 1 zestawiono statystyki finansowania. Jak wykazano, od rozpoczęcia tej inicjatywy łącznie uzyskano kwotę ponad 4,6 miliona euro na realizację 784 projektów. Z tej kwoty ponad 20\% wpłaciły same kasy oszczędnościowe.

Einfach.Gut.Machen z kolei jest inicjatywą Sparkassen-Finanzgruppe, realizowaną od roku 2016. To platforma crowdfundingu donacyjnego bez nagradzania, typu white-label; dostawcą oprogramowania (usług SaaS) jest Table of Visions. Organizacje non-profit, np. szkoły, przedszkola, fundacje itp. mogą bezpłatnie prezentować swoje projekty na platformie (za pomocą tekstów, zdjęć i filmów); zainteresowani sponsorzy mogą bezpośrednio wesprzeć odpowiednie projekty i przekazać żądaną kwotę online. Gromadzenie środków finansowych realizowane jest według zasady All-or-Nothing.

Według stanu na dzień 7 czerwca 2021r. łącznie zgromadzono kwotę ponad 1.3 miliona euro. Obecnie w to przedsięwzięcie zaangażowanych jest 18 kas oszczędnościowych (zob. tabelę 2). Zestawione kasy oszczędnościowe nie publikują zagregowanych statystyk, zatem dane uzyskano poprzez własną agregację wartości i ilości poszczególnych projektów. 
Tabela 2: Kasy oszczędnościowe z platformą regionalną Einfach.gut.machen.de (stan na 7.06.2021r)

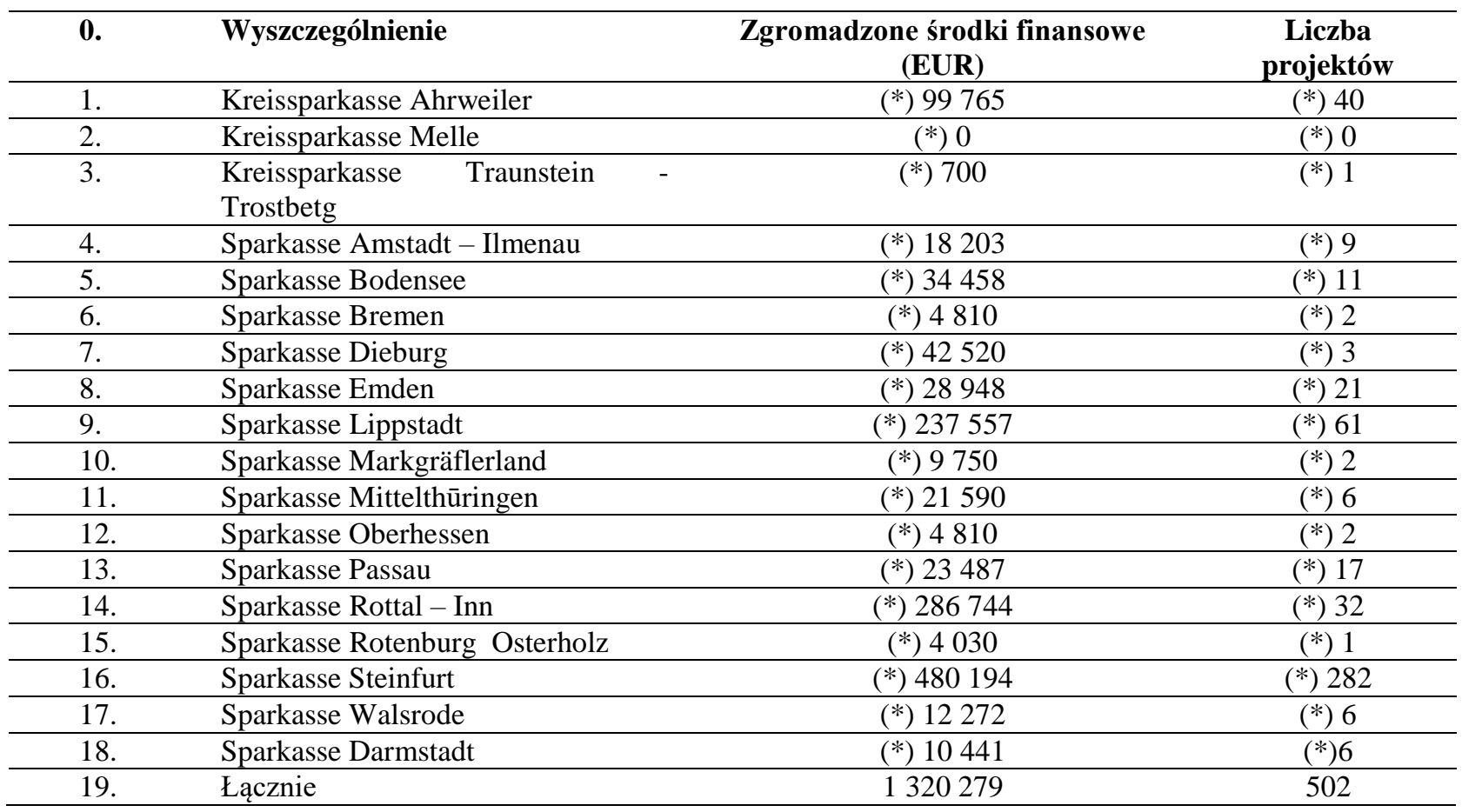

Źródło: zestawienie własne bazujące na statystykach poszczególnych kas oszczędnościowych

(*) agregacja własna; b.d. brak danych

Z inicjatywy Sparkassen-Finanzgruppe wdrażane są od roku 2015 systemy donacyjne „Gut fūr ...”, tzn. „Dobre dla ...” - konkretnych kas oszczędnościowych. Są to następujące platformy: Gut-fuer-Hamburg.de, Gut-fuer-Essen, Gut-fuerMuenchen, Gut-fuer-den-Rems-Murr-Kreis (w Kreissparkasse Waiblingen), Gut-fuer-Koeln-und-Bonn, Gut-fuer-dasWestmuensterland, Gut-fuer-Neckaralb (w Kreissparkasse Tūbingen), Gut-fuer-Wuppertal, Gut-fuer-Ostalb, czy Gutfuer-Mainfranken. Wymienione systemy bazują na koncepcji platformy Betterplace.org; można powiedzieć, że są one subportalami Betterplace.

Tabela 3: Kasy oszczędnościowe wykorzystujące platformę „Gut fūr ...” (stan na 7.06.2021r)

\begin{tabular}{llcc}
\hline Lp. & \multicolumn{1}{c}{ Kasy oszczędnościowe } & $\begin{array}{c}\text { Zagregowane środki } \\
\text { finansowe (w euro) }\end{array}$ & $\begin{array}{c}\text { Liczba sfinalizowanych } \\
\text { projektów }\end{array}$ \\
\hline 1. & Hamburger Sparkasse & 10899479 & 1582 \\
\hline 2. & Sparkasse KölnBonn & 7052976 & 873 \\
\hline 3. & Stadtsparkasse Mūnchen & 6122543 & 1057 \\
\hline 4. & Stadtsparkasse Wuppertal & 2794189 & 567 \\
\hline 5. & Sparkasse Nūrnberg & 1882192 & 575 \\
\hline 6. & Sparkasse Essen & 1683046 & 487 \\
\hline 7. & Sparkasse Westmūnsterland & 1380200 & 426 \\
\hline 8. & Kreissparkasse Ostalb & 1106772 & 339 \\
\hline 9. & Sparkasse Allgäu & 981986 & 322 \\
\hline 10. & Kreissparkasse Tūbingen & 822576 & 477 \\
\hline 11. & Kreissparkasse Waiblingen & 512966 & 197 \\
\hline 12. & Sparkasse Mainfranken Wūrzburg & 402524 & 7064 \\
\hline & Łącznie & 35641449 & 7064 \\
\hline
\end{tabular}

Źródło: zestawienie własne bazujące na statystykach poszczególnych kas oszczędnościowych

W badaniach udało się zidentyfikować 12 takich przedsięwzięć (systemów), zestawionych w tabeli 3, które łącznie zgromadziły kwotę ponad 35.6 mlliona euro na realizację 7064 projektów.

Kolejną inicjatywą Grupy Finansowej Sparkassen jest charytatywna platforma crowdfundingu regionalnego WirWunder.de. Kasy oszczędnościowe współpracują tu z dostawcą usług - platformą Betterplace.org; bazując na tym systemie tworzone są regionalne rozwiązania. Przeprowadzone badania wykazały, że wdrożeń WirWunder.de dokonano (od 2020r) już w co najmniej 46 kasach oszczędnościowych ${ }^{\text {iii }}$. Nie są zwykle udostępniane statystyki dla poszczególnych kas, ale łączne dane wynoszą (https://www.wirwunder.de) 5356692 euro na realizację 1845 projektów. 
Podobnie jest $\mathrm{z}$ platformą donacyjną bez nagradzania Wir-bewegen.sh - nie są udostępniane statystyki dla poszczególnych kas, ale łączne dane (https://wir-bewegen.sh): 986476 EUR i finalizacja 418 projektów; wskazano też, że wskaźnik sukcesu realizacji projektów wyniósł 88\%. Wir-bewegen pierwotnie wdrożono w Investionsbank Schleswig-Holstein (2015r), a następnie (jako white label) w lokalnych kasach oszczędnościowych: Sparkasse Schleswig-Holstein, Sparkasse Holstein, Sparkasse Südholstein, Sparkasse Mittelholstein, Sparkasse Westholstein, Kreissparkasse Herzogtum Lauenburg.

Reasumując, Sparkassen-Finanzgruppe GmbH \& Co. KG grupuje 376 kas oszczędnościowych (Sparkasse, 2021). Jak dotąd, relatywnie niewiele $\mathrm{z}$ nich wdrożyło analizowane platformy crowdfundingu, ale $\mathrm{z}$ drugiej strony systematycznie wzrasta ich liczba, dynamicznie wzrastają pozyskane kwoty. Agregując pozyskane dane można stwierdzić, że implementacji tych systemów dokonano w co najmniej 109 kasach oszczędnościowych, uzyskując łączną kwotę ok. 48 mln euro na realizację 10607 projektów.

\section{VIELE-SCHAFFEN-MEHR W BANKACH VR JAKO STUDIUM PRZYPADKU}

Rozpatrzmy z kolei Viele-schaffen-mehr („Wielu tworzy więcej”), platformę typu white-label, opracowaną przez VR-Networld, Startnext Network oraz Multimedia Solutions, spółkę zależną T-Systems; dostawcą usług SaaS jest tu Startnext.de, największa platforma crowdfundingu w Niemczech. To pierwsza aplikacja crowdfundingu dla sektora finansowego w Niemczech, dostępna online.

Analizowana platforma jest inicjatywą Volksbanken Raiffeisenbanken, służącą do finansowania lokalnych/regionalnych projektów typu non-profit. Funkcjonuje według modelu charytatywnego i zasady All-or-Nothing. Omawiana inicjatywa jest niezwykle istotna ze względów społecznych - promuje w regionie zaangażowanie społeczne. Jest ponadto znakomitym przykładem (Benz, 2013), w jaki sposób lokalne banki mogą wykorzystywać media społecznościowe.

Pierwszego wdrożenia dokonano w Volksbanku Bühl w roku 2013, a masowe implementacje w innych oddziałach miały miejsce w kolejnych latach, przy czym niektóre banki dokonały tego dopiero w 2021 roku. Celem platformy jest zapewnienie lokalnego finansowania inicjatyw lokalnych. Przykładowo (Telekom, 2013), jeśli klub sportowy chce wyremontować trybuny na swoim boisku, może szukać wsparcia finansowego od mieszkańców gminy, powiatu, wsi lub powiatu na stronie www.viele-schaffen-mehr.de. Gdy zakładany cel finansowania zostanie osiągnięty, projekt będzie realizowany, natomiast jeśli cel nie zostanie osiągnięty, zgromadzone środki są zwracane darczyńcom. Ani darczyńcy, ani inicjatorzy projektów nie wnoszą opłat za korzystanie z platformy.

Koncepcja finansowania społecznościowego jest zbieżna z zasadą spółdzielczości Volksbanku: to, czego jednostka nie może osiągnąć w pojedynkę, ponosi i realizuje wspólnota („Czego nie można zrobić samemu, wielu może uczynić”). Idea crowdfundingu nawiązuje do tego pomysłu, gdyż ci, którzy nie mogą np. samodzielnie wyremontować swojego boiska itp. mają teraz szansę na realizację projektów za pośrednictwem viele-schaffen-mehr.de (Monz, 2013). Volksbank Bühl na wiele sposobów wspiera inicjatorów projektów. Dostępny jest m.in. system web-to-print, do projektowania i drukowania materiałów reklamowych bez konieczności posiadania specjalistycznej wiedzy marketingowej. Bank reklamuje te projekty na swoich stronach Web i w swoich oddziałach. Obsługiwana jest integracja z Facebookiem i innymi mediami społecznościowymi (Ibidem).

Projekty grupowane są w następujące kategorie: Ogólna; Edukacja; Regionalne zwyczaje; Dzieci i młodzież; Kultura i sztuka; Muzyka; Przykładowe projekty; Zaangażowanie społeczne; Sport i spędzanie wolnego czasu; Zwierzęta i środowisko. Od niedawna intensywna jest realizacja projektów dotyczących pandemii COVID-19.

Wart szerszej prezentacji jest przykład Münchner Banku (Münchner Bank, 2020), w którym również wdrożono system Viele schaffen mehr. Platforma crowdfundingu przenosi motto spółdzielcze w erę cyfrową i udowadnia, co jest możliwe, gdy wiele osób pomaga razem. W 2020 roku przyczyniono się do realizacji 32 projektów charytatywnych w Monachium i okolicach, gromadząc od ponad 1500 darczyńców kwotę 116614 euro (Ibidem). Obserwuje się dynamiczny wzrost pozyskiwanych wartości: według stanu na 7 czerwca 2021r. było to już ok. 351396 euro, czyli ponad trzykrotnie więcej. Monachijskie organizacje non-profit mogą od 2020r. zgłaszać własne projekty charytatywne w nowej kategorii „Coronawirus". Organizowano też konkursy na realizację projektów; w jednym z nich jury wybrało 8 projektów. Lokalna prasa (AZ) wsparła inicjatywę reklamami, a Münchner Bank eG znaczną dotacją finansową - nie tylko dodawano kolejne 10 euro za każdą darowiznę w wysokości min. 5 euro, ale i dofinansowano najlepszy projekt, tak, że szybko osiągnął co najmniej 80\% zakładanego celu finansowego. Wspólnie zebrano ok. 25000 euro w zaledwie trzy tygodnie. A ponieważ pozostałe projekty z preselekcji jury również były ważne, każdy z nich otrzymał od banku po 500 euro, zaś wśród darczyńców zostały rozlosowane nagrody (Ibidem: 21).

Szczególną cechą platformy Viele-schaffen-mehr jest to, że każdy projekt, zakwalifikowany na platformę, jest wspierany przez współfinansowanie z Volks-/Raiffeisenbank. Oznacza to, że bank wnosi wkład własny za sponsora, który uczestniczy w finansowaniu projektu za pośrednictwem platformy crowdfundingu. Banki współfinansują realizację projektów, np.:

a) Volksbank Bühl eG - zgromadzono 232 541,62 EUR, w tym 29320 EUR to dofinansowanie banku;

b) Volksbank Pforzheim eG - kwota 150126,77 EUR, w tym 50653 EUR współfinansowanie; 
c) VR - Bank Bad Kissingen eG - kwota 187596,81 EUR, w tym 49360 EUR dofinansowanie;

d) Volksbank - Raiffeisenbank Vilshofen eG - uzyskano 102161,61 euro (w tym 44136 euro dofinansowanie);

e) Volksbank Hellweg eG - kwota 1053849,09 EUR, w tym 96299 EUR to dofinansowanie banku.

Projekty są zatem dofinansowywane w różnej wartości, stosowane są różne strategie. Wśród w./wym. udział dofinansowania kształtował się na poziomie 9\% (w przypadku Volksbank Hellweg), 12\% (Volksbank Bühl), 26\% (VR - Bank Bad Kissingen), ok. 34\% (Volksbank Pforzheim), ponad 43\% (VR - Bank Vilshofen).

Analizując cały zbiór implementacji, współfinansowanie jest zwykle realizowane na poziomie 9 - 20\%, przy czym najwyższy udział dotacji spotykamy w Volksbank Haale (Saale) eG (48\%).

Według pracy (Monz, 2013), darowizny od pierwszych 2000 darczyńców były wspierane przez Volksbank Bühl kwotą 5 euro każda; łącznie bank przeznaczył (w pierwszych latach) na ten cel 10000 euro. Podobną strategię wykorzystano w innych bankach. W przypadku Volksbanken Kaiserlautern eG (2017), współfinansowanie obejmuje dopłaty po 5 euro (przy wpłatach co najmniej 5 euro) oraz tzw. „premię startową” w wysokości 250 EUR. Według (Marktspiegel, 2020), Volksbank Hildesheim-Lehrte-Pappensen przeznaczył pulę 20 tys. euro, aby podwajać każde jednostkowe finansowanie do maksymalnej kwoty 100 euro.

\section{CROWDFUNDING W BANKACH VR - WYNIKI BADAŃ}

Obecnie funkcjonuje ponad 1100 oddziałów regionalnych VR Banku, ale nie we wszystkich dokonano wdrożeń badanej platformy. W przeprowadzanych badaniach zidentyfikowano 192 implementacje systemu Viele-schaffen-mehr (dodatkowo, niektóre agregowały po kilka filii). W kilku przypadkach dokonano własnej agregacji pozyskiwanych środków z poszczególnych sfinalizowanych projektów.

W Raiffeisen-Volksbank poprzez platformę Viele-schaffen-meht łącznie pozyskano ponad 38 mln EUR (38485894.18). Dla porównania (Landessportbund, 2019), do końca listopada 2018r. internetowe portale grupy VolksRaiffeisenbanken, biorące udział w inicjatywie, zgromadziły 16919313.60 euro (tj. kwotę ponad dwukrotnie mniejszą) na 4083 projekty charytatywne od 396752 darczyńców.

Ze względów organizacyjnych nie jest możliwe w niniejszej pracy zestawienie tabelaryczne wszystkich zidentyfikowanych wdrożeń, wraz z pozyskiwanymi statystykami (zgromadzonych środków finansowych oraz liczby projektów). W tym zbiorze zidentyfikowano: 19 banków z kwotami powyżej 0,5 miliona euro, 42 z kwotami z zakresu ponad 200 tys. - 500 tys. euro, 45 z kwotami z zakresu 100 tys. - 200 tys. euro oraz 44 z pozostałymi wartościami. W ok. 22\% przypadków nie udostępniano statystyk crowdfundingu lub ze względów technicznych nie była dostępna strona Web z takimi danymi.

Tabela 4: Struktura gromadzonych środków finansowych (stan na 7.06.2021r.)

\begin{tabular}{lll}
\hline Zakres gromadzonych kwot (EUR) & Liczba wdrożeń & Udzial procentowy \\
\hline 1 milion i powyżej & 3 & 1.5 \\
\hline $500000-999999$ & 16 & 8.3 \\
\hline $200000-499999$ & 42 & 21.9 \\
\hline $0-199999$ & 89 & 46.4 \\
\hline brak danych & 42 & 21.9 \\
\hline Łącznie & 192 & 100.0 \\
\hline
\end{tabular}

Źródło: opracowanie własne

Struktura gromadzonych środków finansowych jest asymetryczna (zob. tabela 4). Im większe wartości, tym mniej takich implementacji. Niemalże połowa wdrożeń dotyczy kwot do 200 tys. euro. Kwoty ponad 1 mln euro uzyskano zaledwie w trzech bankach: Volksbank Hellweg eG, Volksbank Allgau-Oberschwaberg eG oraz Volksbank Stuttgart eG, łącznie uzyskując ok. 3.058 miliona euro.

\section{OGRANICZENIA METODY BADAWCZEJ}

Zaproponowana metoda wiąże się z kilkoma ograniczeniami:

- Umożliwia pomiar wielkości i struktury gromadzonych środków finansowych, realizację postawionych celów, choć z drugiej strony uzyskane wartości odnoszą się tylko do konkretnego punktu czasowego (7 czerwca 2021 r.). Jednakże w dalszej perspektywie stwarza to możliwość porównywania badań w innych punktach czasowych.

- Realizacja badań zależna jest od dostępu do danych i o odpowiedniej jakości (choć tę jakość gwarantują analizowane instytucje wiarygodności społecznej);

- Rozważania poświęcono jedynie wybranemu segmentowi sektora finansowego, ale w praktyce gospodarczej, spośród banków najwięcej aplikacji crowdfundingu w takich instytucjach i to w skali świata zrealizowano właśnie w Niemczech. 


\section{PODSUMOWANIE. KIERUNKI DALSZYCH BADAŃ}

Mimo że literatura naukowa z zakresu crowdfundingu jest dziś bogata i różnorodna, to publikacje na temat zastosowań tej metody w instytucjach finansowych niemalże nie występują. W niniejszym artykule udało się zbadać specyficzny sub-segment rynkowy - kasy niemieckie oszczędnościowe i banki Volksbanken Raiffeisenbanken, wdrażające platformy crowdfundingu. Określono zakres implementacji takich systemów identyfikując poszczególne analizowane instytucje finansowe. Uwypuklono metody współfinansowania projektów. Dokonano pomiaru wartości gromadzonych środków finansowych (kapitału) i zakresu realizacji projektów. W badanym segmencie zidentyfikowano 6 platform crowdfundingu, które łącznie pozyskały relatywnie dużą kwotę, ponad 86.3 miliona euro, a wdrożeń dokonano w co najmniej 301 bankach i kasach.

Poznanie specyfiki i wydzielenie rozmiarów (w kategoriach wartościowych i ilościowych) sub-segmentu crowdfundingu w niemieckich kasach oszczędnościowych i bankach VR, choć cząstkowe, wydaje się perspektywiczne. Otwiera pulę dalszych badań w tym zakresie $\mathrm{z}$ możliwością ich porównywania. Możliwe będzie analizowanie zastosowań crowdfundingu (także według innych modeli funkcjonowania, czy według innych metod gromadzenia środków finansowych) w innych bankach, w skali świata. Wskazane są również oceny skuteczności realizowania poszczególnych kampanii crowdfundingu, w tym pomiar wskaźników sukcesu.

Powracając do paradoksu sformułowanego uprzednio w tym artykule, można postawić pytanie: dlaczego banki implementują systemy crowdfundingu. Ta problematyka wymaga dalszych badań i studiów, jednak analizowane kasy oszczędnościowe i banki uzyskują istotne korzyści z wykorzystywania crowdfundingu. To między innymi budowanie marki i nowego modelu biznesowego - tworzenie bliższych więzi klientów z instytucjami finansowymi. Zaprezentowane inicjatywy implikują zwiększenie zaangażowania społecznego, kapitału społecznego, co ma bezpośredni wpływ na promowanie np. lokalnej (regionalnej) kultury i rozwój gospodarczy. Udostępnianie przez banki platform do realizacji projektów różnych instytucji non-profit i stowarzyszeń, a zwłaszcza dofinansowywanie tych przedsięwzięć przez instytucje finansowe wydaje się szczególnie istotne dziś, w dobie kryzysu wywołanego pandemią COVID-19. W oczywisty sposób wspiera to organizacje non-profit, obecnie znajdujące się pod presją finansową, w zabezpieczaniu ich ekonomicznej egzystencji.

\section{BIBLIOGRAFIA}

1. Agrawal, A., Catalini Ch. \& Goldfarb A. (2011). The Geography of Crowdfunding, The National Bureau of Economic Research (NBER). NBER Working Paper, no. 16820, February. https://doi.org/10.3386/w16820

2. Agrawal, A., Catalini Ch. \& Goldfarb A. (2013). Some Simple Economics of Crowdfunding. The National Bureau of Economc Research. NBER Working Paper, No. 19133. https://doi.org/10.3386/w19133

3. Agrawal, A., Catalini Ch. \& Goldfarb A. (2013). Crowdfunding: Social Frictions in the Flat World?. University of Toronto, NBER Working Paper, 14 October.

4. Agrawal, A., Catalini, C. \& Goldfarb, A. (2015). Crowdfunding: Geography, Social Networks, and the Timing of Investment Decisions. Journal of Economics \& Management Strategy, 24, 253-274. http://dx.doi.org/10. 1111/jems.12093.

5. Belleflamme, P., Lambert, T. \& Schwienbacher, A. (2010). Crowdfunding. An Industrial Organization Perspective, http://economix.fr/pdf/workshops/2010_dbm/Belleflamme al.pdf

6. Belleflamme, P., Lambert, T. \& Schwienbacher, A. (2012). Crowdfunding. Tapping the right crowd. Working Paper. online http://ssrn.com/abstract=1578175. https://doi.org/10.2139/ssrn.1836873

7. Belleflamme, P., Lambert, T. \& Schwienbacher, A. (2013). Individual Crowd-funding Practices. Venture Capital, 15(4), https://doi.org/10.2139/ssrn.2151179

8. Belleflamme, P., Lambert, T. \& Schwienbacher, A. (2014). Crowdfunding: Tapping the Right Crowd, Journal of Business Venturing, 29(5), 585-609. https://doi.org/10.1016/j.jbusvent.2013.07.003

9. Benz, J. (2013). Social Media is not just Facebook. It's more about company culture and attitudes towards innovation. 15 July, https://blog.gift.com/

10. Borello, G., Crescenzo V. de \& Pichler, F. (2015). The Funding Gap and the Role of Financial Return. Crowdfunding: Some Evidence From European Platforms. Journal of Internet Banking and Commerce, 20(1).

11. Dapp, T. F. (2013). Crowdfunding: An alternative source of funding with potential, In Banking Technology Snapshot. Deutsche Bank Research, Deutsche Bank AG, Frankfurt am Main.

12. Dziuba, D.T. (2021). Crowdfunding korporacyjny. Difin, Warszawa.

13. Dziuba, D.T. (2015). Ekonomika crowdfundingu. Zarys problematyki badawczej. Difin, Warszawa.

14. Estellés-Arolas, E., González, L. \& Guevara, F. (2012). Towards an integrated crowdsourcing definitions. Journal of Information Science, 38(2), 189-200. https://doi.org/10.1177/0165551512437638

15. Lambert, T. \& Schwienbacher, A. (2010). An Empirical Analysis of Crowdfunding. Université catholique de Louvain \& Univerity of Amsterdam, Business School. SSRN Electronic Journal 1-23.

16. Landessportbund, Nordrhein-Westfalen (2019). Viele schaffen mehr. Volksbanken und Raiffeisenbanken fördern gesellschaftliches Engagement vor Ort!, https://www.vibss.de/

17. Marktspiegel (2020). Viele schaffen mehr. Volksbank bietet Crowdfunding-Plattform, https://www.marktsp iegel-verlag.de/ 
18. Menon, K., Kärkkäinen, H., Jussila, J., Huhtamäki, J., Mukkamala, R. R., Lasrado, L. A., Vatrapu R. \& Hussain, A. (2018). Analysing the role of crowdfunding in entrepreneurial ecosystems. A social media event study of two compating product launches, Entrepreneurship and Small Business, 4(33), 575-606. https://doi.org/10.1504/IJ ESB.2018.090363

19. Mollick, E. R. (2012). The Dynamics of Crowdfunding: Determinants of Success and Failure. Draft document, 25 July, The Wharton School of the University of Pennsylvania; SSRN. https://doi.org/10.2139/ssrn.2088298

20. Mollick, E. R. (2013). Swept Away by the Crowd? Crowdfunding, Venture Capital, and the Selection of Entrepreneurs. University of Pennsylvania - Wharton School; SSRN, http://ssrn.com/abstract=2239204. https://doi.org/10.2139/ssrn.2239204

21. Mollick, E. R. (2014). The Dynamics of Crowdfunding: An Exploratory Study. Journal of Business Venturing, 1 (29): 1-16. https://doi.org/10.1016/j.jbusvent.2013.06.005

22. Mollick, E. R. (2016). The Unique Value of Crowdfunding Is Not Money - It`s Community. Harvard Business Review, April 21.

23. Monz, S. (2013). Crowdfunding bei der Volksbank Bühl, 10 Mai, https://www.ruv- blog.de/

24. Münchner Bank (2020). Viele schaffen mehr \& gutes vereint. In Münchner Bank eG, Stark und verlässlich. Geschäftsberich 2020.

25. Pietro, Di F. (2020). Crowdfunding for Entrepreneurs. Developing Strategic Advantage through Entrepreneurial Finance. Routledge, Taylor \& Francis Group, London - New York. https://doi.org/10.4324/ 9780429319785

26. Ryu, S. (2020). Beauty of Crowdfunding. Blooming Creativity and Innovation in the Digital Era. Routledge, Taylor \& Francis Group, London - New York. https://doi.org/10.4324/9780429243714

27. Schwienbacher, A. \& Larralde, B. (2010). Crowdfunding of Small Entrepreneurial Ventures. In Handbook of Entrepreneurial Finance, Oxford University Press, Oxford. https://doi.org/10.2139/ssrn.1699183

28. Shneor, R., Zhao, L. \& Flaten, B.-T., eds. (2020). Advances in Crowdfunding. Research and Practice. Palgrave Macmillan. https://doi.org/10.1007/978-3-030-46309-0

29. Sparkasse (2021). Wir über uns: Stark im Verbund, https://www.sparkasse.de/

30. Telekom (2013). New crowdfunding model for the financial media sector: T-Systems supports platform for crowd financing, 22 May, https://www.telekom.com/.

31. Volksbanken Kaiserlautern eG (2017). Crowdfunding-Projekte erfolgreich, https://www.vobakl.de/

32. Wash, R. (2013). The Value of Completing Crowdfunding Projects, Proceedings of the International Conference on Weblogs and Social Media, Boston, MA, July.

\section{PRZYPISY}

\footnotetext{
${ }^{\mathrm{i}}$ Uwypuklono wybrane modele crowdfundingu. Szersze ujęcie tej problematyki w pracy autora (Dziuba, 2015).

${ }^{i i}$ Spośród takich implementacji według modelu donacyjnego wymieniam platformy Klicken \& Helfen; Heimetlieben, mainFrankfurt oraz Gemeinsam\#GutesTun.

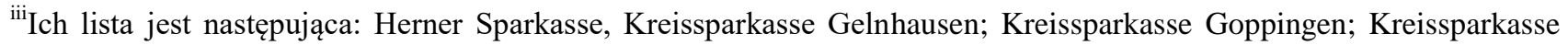
Ludwigsburg; Kreissparkasse Rottweil; Kreissparkasse Saarpfalz; Kreissparkasse Schwalm-Eder; Kreissparkasse Weilburg; Kreissparkasse Wiedenbruck; OstseeSparkasse Rostock; Sparkasse Aichach - Schrobenhausen; Sparkasse Bad Pyrmont; Sparkasse Bochum; Sparkasse Bonndorf-Stūhlingen; Sparkasse Bottrop; Sparkasse Deggendorf; Sparkasse Dillenburg; Sparkasse Duisburg; Sparkasse Dūren; Sparkasse Freyung - Grafenau; Sparkasse Gelsenkirchen; Sparkasse Hagentlerdecke; Sparkasse Hamm; Sparkasse Hannover; Sparkasse Hattingen; Sparkasse Hochsauerland; Sparkasse Hőxter; Sparkasse Jena - Saale - Holzland; Sparkasse Kraichgau; Sparkasse Landsberg - Diessen; Sparkasse Landshut; Sparkasse Lerngo; Sparkasse Mecklenburg - Schwerin; Sparkasse Mūlheim an der Ruhr; Sparkasse Olpe Drolshagen - Wenden; Sparkasse Paderborn - Detmold; Sparkasse Rotenburg Osterholz; Sparkasse Saarbrucken; Sparkasse Uelzen Lūchow - Dannenberg; Sparkasse Ulm; Sparkasse Wilhelmshaven; Stadt-Sparkasse Langenfeld; Stadtsparkasse Lengerich; Stadtsparkasse Wedel; VerbundSparkasse Emsdetten-Ochtrup; Weser - Elbe Sparkasse.
} 